\title{
Моделювання процесу конвективного теплообміну маслом 3 поверхні розподільчого трансформатора
}

\author{
Ю.В. Байдак ${ }^{1 \rrbracket}$, М. Масарік $^{2}$, В.А. Матухно ${ }^{3}$ \\ ${ }^{1}$ Одеська національна академія харчових технологій, вул. Канатна, 112, 65039, Одеса, Україна \\ ${ }^{2}$ Словацький технологічний університет, факультет механіки, вул. Наместьє Слободи, 17, 82131 Братислава, \\ Словацька Республіка \\ ${ }^{3}$ Одеський національний політехнічний університет, пр. Шевченка, 1, Одеса, 65044, Україна \\ $\bowtie$ e-mail: kozak_admin@ukr.net
}

Результатом роботи є обгрунтування доцільності впровадження результатів моделювання рівнянь теплового балансу, складених для активної частини розподільчого трансформатора напруги, на стадії його завершального і уточнюючого етапу проектування. Активна частина знаходиться в середовищі трансформаторного масла, а тепловіддача здійснюється теплопередачею та конвекцією. Математична модель теплового балансу відповідає еквівалентній тепловій схемі заміщення, складеної з двох суміжних вузлів зі стоками тепла - узагальненої обмотки і реромагнітного стрижня та третього суміжного з ними вузла - рухомої речовини з масла, яке додатково контактує з навколишнім середовищем нескінченної теплоємності. Рішення рівнянь отримані для середнього значення температур обмотки, стрижня магнітопроводу і масла в функції часу, що дозволяє встановити очікувані їх значення упродовж роботи трансформатора $i$, особливо, з нерівномірним графіком його навантаження, а також здійснювати обгрунтований вибір магнітної індукції в стрижні магнітопроводу і густини струму в обмотках за показником припустимих в них температур нагріву.

Ключові слова: Моделювання; Розподільчий трансформатор; Тепловий баланс; Часові діаграми температур; Графік навантаження; Теплова підсистема

DOI: http://dx.doi.org/10.15673/ret.v53i1.542

(C) The Author(s) 2017. This article is an open access publication

This work is licensed under the Creative Commons Attribution 4.0 International License (CC BY) http://creativecommons.org/licenses/by/4.0/

\section{1 Вступ}

Розподільчі трансформатори потужністю до 25000 кВА масово застосовуються у електричних мережах для перетворення напруги живлення 10/6 кВ у 0,4 кВ і призначені для живлення електричною енергією малих підприємств та мешканців районів у містах, селищах тощо. Враховуючи графік споживання електричної енергії, який змінюється упродовж року - зима, літо та щодобово - ранок, вечір, змінюється і навантаження трансформаторів та їх температура, джерелом тепла якого $€$ сталі втрати потужності в магнітопроводі і змінні втрати в обмотках.

При експлуатації електрообладнання і проектуванні, завжди існує необхідність вирішувати задачу його нагрівання та охолодження, а саме найбільш вразливого елементу конструкції - ізоляції обмоток. Успішне вирішення задачі сприятиме створенню економічно надійного обладнання та утворення обґрунтованого режиму експлуатації. Тривалий режим навантаження в умовах існування постійних втрат електричної енергії призводить до встановлення значних температур на найбільш вразливих ділянках активної частини трансформаторів, чим суттєво скорочує термін їх придатності.
Для поліпшення стану старіння ізоляції зниженням її перегріву, при проектуванні електрообладнання закладають занижені лінійні навантаження - магнітну індукцію в осередді магнітопроводу і густину струму в обмотках, що призводить до зростання масогабаритних показників обладнання. 3 іншого боку температури, нижчі за нормовану у 60ㄷ, вказують на мале використання закладеної у обладнання маси активних матеріалів. Незважаючи на такий стан, питання, пов'язані із розрахунком теплових режимів в динаміці і статиці, $€$ найменш розробленим напрямком галузі створення сучасного електрообладнання, а ті методи, якими вони вирішуються, мають похибку більшу за 10\%, що є неприпустимим [22].

\section{2 Аналіз існуючих методів урахування нагріву і охолодження розподільчих трансформаторів}

Основні припущення щодо протікання процесу нагріву і охолодження РТ в цілому або у окремих елементах його конструкції, а також методи, що застосовуються для гідравлічного і теплового розрахунку, викладено у роботах $[9,10,11]$. Найбільш сучасні 3 них наведено у 
[14-23], де також запропоновано їх класифікацію по чотирьом групам, а саме:

1. Емпіричний метод «перегрівів» [14], оснований на використанні усереднених емпіричних коефіцієнтів тепловіддачі по вертикальній і горизонтальній поверхням котушок разом із спрощеним урахуванням температури масла по висоті котушок та також на підсумовуванні перевищень температури поверхонь провідників котушок над маслом і перепаду температури у товщині ізоляції елементарних провідників та у їх спільній ізоляції;

2. Розрахунковий метод перегрівів, при якому коефіцієнти тепловіддачі визначають розрахунком [15];

3. Метод термогідравлічних кіл, як у міжкотушковому просторі обмоток [16,17], так і для загального теплового і гідравлічного кола трансформатора із урахуванням застосованої системи охолодження [18];

4 .Метод польового моделювання теплового, гідростатичного і гідродинамічного стану обмоток [18-22], заснований на чисельних рішеннях повної системи рівнянь Нав'є-Стокса із різноманітними додатковими спрощеннями при постановці і вирішенні задачі.

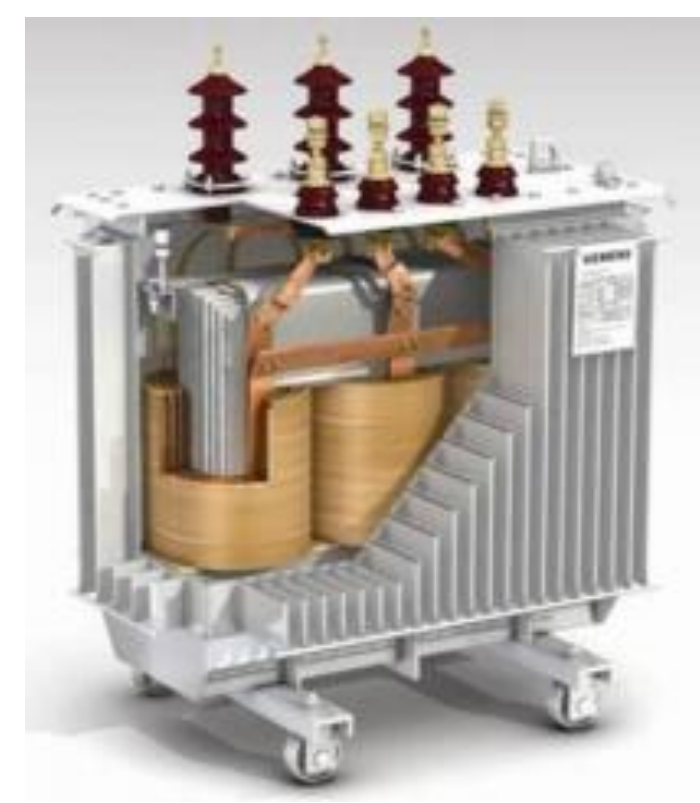

Рисунок 1 - Зовнішній вигляд розподільчого трансформатора та його активної частини, яка знаходиться у середовищі охолоджуючого масла

\section{Особливості означених методів наведено далі.}

Емпіричний метод «перегріву» наведено у роботі [14] та оглядово у [9]. Його засновано на апріорних даних результатів експериментальних випробувань явища теплообміну в модельних та природних котушкових і циліндричних обмотках. Метод досі є базовим для виробників трансформаторів в Україні. Початковими даними щодо його застосування $€$ геометричні розміри джерел тепла, коефіцієнтів теплопровідності окремих елементів конструкції (міжшарової ізоляції провідників струму, ізоляції дротів, ізоляційних циліндрів тощо), а також такі теплові характеристики як середня температура масла у баку, перевищення середньої температури масла в баку і температури верхнього шару масла над температурою охолоджуючого середовища. Ці теплові дані отримуються з окремого балансового електромагнітного розрахунку усієї системи, яка включає трансформатор із зовнішнім теплообмінником для охолодження масла, що циркулює у системі. Результати попереднього аналізу надаються у вигляді сукупності емпіричних степеневих залежностей перевищень середньої температури поверхні обмоток (котушки) над середньою температурою масла в баку - від ряду режимних і геометричних параметрів, а саме: густини теплового потоку для обмотки (котушки), що розглядається; відношення радіальної ширини обмотки до висоти горизонтального каналу між котушками для котушкових обмоток; ширини внутрішнього і зовнішнього вертикальних охолоджуючих каналів, середньої температури масла в баку і середньої швидкості примусового руху масла в баку для зовнішніх обмоток при системі охолодження ДЦ та Ц. Розрахунок виконується для декількох характерних зон (блоків котушок) трансформатора. Для обмотки або окремих груп котушок розраховується перевищення середньої температури поверхні і об'єму обмотки над середньою температурою масла в баку трансформатора, перевищення середньої температури обмотки у найбільш нагрітої точці (НHТ) над температурою охолоджуючого середовища. Адже придатність методу обмежена вивченим діапазоном основних факторів. Спрощено визначається температура ННТ в обмотці, яка характеризує навантажувальну здатність трансформатора. Отримання нових даних, які $б$ розширили діапазон застосування методу та уточнювали його на підставі результатів фізичного моделювання, потребують значних часових, фінансових вкладень (виготовлення моделей, випробування) та інших ресурсів, а тому цей метод у подальшому не отримав розвитку.

Розрахунковий метод «перегрівів» [15] в меншій мірі обмежений емпіричними даними. Метод базується на опису основних фізичних закономірностей гідродинаміки і теплообміну при природній та вимушеній (сумісній) конвекції масла у вертикальних каналах обмоток за допомогою безрозмірних критеріальних співвідношень в яких тільки коефіцієнти, залежні від типу і розмірів обмотки, встановлюються на підставі дослідних даних. Тим не менше, метод спрощено визначає значення температури ННТ так як базовим розрахунковим елементом постає узагальнена модель котушки із усередненими втратами в усіх провідниках. В той же час відомо, що величина втрат в окремих провідниках по радіальному розміру котушки може значно відрізнятися у зв'язку з тим, що має місце нерівномірний розподіл радіальної та осьової складових індукції магнітного поля, які спричиняють відповідні додаткові втрати потужності в провідниках (поверхневий ефект). Обмеженням щодо застосування методу слід вважати великий діапазон емпіричних даних по типу і розмірам обмоток.

Метод еквівалентних теплогідравлічних кіл [16, $17,18]$ отримав розповсюдження завдяки розробці методу теплового розрахунку для складних багатомірних 
об'єктів в суцільних середовищах трансформаторів для яких системи диференційних рівнянь в часткових похідних замінюються нуль мірними тепловими і гідравлічними колами із сукупністю зосередженої теплової та гідравлічної провідності, тепловими ємностями $[16,17]$. Ці кола описуються звичними диференційними рівняннями першого порядку, які у кінцевому вигляді замінюються системою алгебраїчних рівнянь для стаціонарних задач. Застосування цих схем спрощує процедуру термогідравлічних розрахунків, однак необхідність використання в них емпіричних, а тому не завжди надійних і точних даних по коефіцієнтам локальних гідравлічних опорів, несе в собі потенційні похибки при розрахунку перепаду тиску і витрат в каналах зовнішнього і внутрішнього контурів охолодження. Згідно до методу, розрахунок процесів гідродинаміки і теплообміну маслом у складній конструкції трансформатора зазвичай здійснюється у два етапи. На першому етапі розраховується гідравлічна частина трансформатора з метою визначення масової витрати масла у зовнішньому контурі охолодження та в обмотках у внутрішньому контурі трансформатора. На цьому етапі використовують так звані схеми заміщення зовнішнього контуру трансформатора для визначення масової витрати масла [18]. На другому етапі, за розрахованою витратою масла, температурами всередині бака і в обмотках, виконують розрахунок перегрівів $[16,17]$. Незважаючи на складність методу, обидва його етапи є приблизними оскільки дозволяють визначити розрахункові величини як усереднені в достатньо великих за розміром і неоднорідних за фізичними властивостями областях.

В роботах [19-23] та аналогічних до них застосовано вирішення нестаціонарного рівняння теплопровідності із джерелами тепло відтоків для анізотропного або ізотропного тіл з використанням чисельних методів. Вплив гідродинамічних процесів на теплоперенос і вплив оточуючого середовища на теплові процеси в трансформаторних системах враховується за допомогою коефіцієнтів тепловіддачі. При цьому отримані вирази не мають достатньої універсальності, а вплив на них швидкості руху масла внаслідок конвективного теплообміну не враховується. Також вважається, що характер течії i значення швидкості масла в системі охолодження $€$ відомими за результатами експериментальних випробувань. Все це у сукупності обмежує галузь застосування такого підходу для реальних трансформаторів і універсальність отриманих результатів. Більш того, швидкість руху масла на різних ділянках всередині баку трансформатора $є$ відмінною і апріорно коливається в межах 0,01...0,6 м/с [22].

Заводський метод теплового розрахунку обмоток трансформатора засновано на розрахунку густини теплового потоку який стікає з поверхні обмоток ВН і НН і на підставі попередньо розрахованих у них основних $P_{k i}$ втрат короткого замикання iі додаткових $P_{\text {дi }}$ які обумовленні другорядними процесами електромагнітного характеру, тобто у вигляді

$$
q_{o i}=\frac{P_{k i}+P_{m i}}{o_{i}}=\frac{1,05 P_{k i}}{o_{i}},
$$

де $O_{i}$ - площа ефективної поверхні охолодження $i^{\text {ої об- }}$ мотки.

За знайденими значеннями густини теплового потоку розраховують середнє теплове навантаження обмоток

$$
q_{\text {om }}=\sum q_{\text {oi }}
$$

яке не повинне відрізнятися більш ніж на $10 . .15$ \% від його значення, прийнятого на початку проектування трансформатора за умови відповідності показнику ефективності.

Для розрахункових значень питомого теплового навантаження, усереднений по поверхням обмоток перегрів над температурою теплоносія, визначається емпірично як

$$
\tau_{\text {omi }}=0,159 q_{o i}^{0,7} .
$$

Що стосується перепаду температури всередині обмоток трансформатора, то він визначається формулою Ньютона, яку надано у вигляді закону Ома, а саме:

$$
\tau_{\text {oi }}=\frac{q_{\text {oi }}}{R_{\text {Teni }}}
$$

У виразі опір на шляху теплового потоку, який передається теплопровідністю в неоднорідному середовищі $R_{\text {mелі }}$ визначається середньою теплопровідністю обмотки і її лінійними розмірами, а отже, коефіцієнтом теплопередачі. Так для обмотки НН тепловий опір становить

$$
R_{\text {тепr. }}=\frac{\lambda_{M}}{t_{\mathrm{Bm}}{ }^{3}}
$$

а для обмотки $\mathrm{BH}-$

$$
R_{\text {тепr. }}=\frac{8 \lambda_{\mathrm{M}}\left(d_{\mathrm{mn}}+t_{\mathrm{M}}\right)}{t_{\mathrm{M}}+0,7 \lambda_{\mathrm{M}} \cdot d_{\mathrm{Mn}} \sqrt{\frac{d_{\mathrm{Mn}}-d}{d}} x}
$$

У виразах $(5,6) \quad \lambda_{u}$ - теплопровідність просоченої лаком паперової ізоляції дроту, що разом розташовані в маслі, $t_{\mathrm{Bm}}$ - товщина ізоляції дроту на одну сторону, $d_{\mathrm{mu}}-$ діаметр ізольованого дроту, $t_{\mathrm{M}}$ - товщина міжшарової ізоляції, $d$ - діаметр голого дроту. Звідси, середній перепад температури обмотки ВН, при умові її лінійного розподілу по висоті, рекомендовано визначати за співвідношенням

$$
\tau_{o \mathrm{BHcp}}=\frac{2}{3} \tau_{\mathrm{oBH}}
$$

Що стосується втрат потужності в магнітопроводі, як джерелі тепла, то ними нехтують в тепловому розрахунку не дивлячись на те, що вони одного порядку з втратами потужності в обмотках трансформатора. Такий підхід для урахування теплового навантаження в трансформаторі під час проектування на номінальну потужність може застосовуватись, але в умовах змінного графіку навантаження упродовж експлуатації $€$ неприємним. 
Більш того усереднені показники теплового навантаження не враховують локальних перегрівів обмоток по висоті котушок і особливо на ділянках з складним теплообміном між обмотками і теплоносієм - під ярмом магнітопроводу, діелектричними прокладками тощо. Розглядаючи трансформатор тільки як теплову підсистему, метод не враховує гідравлічних процесів, пов'язаних з рухом теплоносія, а, отже, - впливу швидкості теплоносія на розподіл поля температур в маслі і самої температури - на зміну його динамічної в'язкості, швидкості теплового потоку, залежності коефіцієнту теплопередачі від температури обмоток. Такі припущення $є$ неприємними в умовах роботи РТ з дуже нерівномірним графіком навантаження, які мають місце при віялових відключеннях споживачів і повинні бути врахованими під час його проектування.

Дослідження тепловіддачі циліндричних обмоток мають велике значення під час проектування РТ із урахуванням теплового навантаження. Так у роботі [1] вказується, що середня швидкість руху масла в баку трансформатора складає 0,01...0,05 м/с (за даними [22] 0,1...0,6 м/с) і його напрям співпадає з природнім рухом під дією конвекції та гравітації. Результати отриманих експериментальних випробувань засновані на тому, що температурне поле циліндричної обмотки із двосторонніми охолоджуючими каналами і рівномірно розподіленими внутрішніми джерелами тепла у порівнянні з заводським методом визначаються рівнянням параболи другого порядку [2]. Для таких обмоток середній перепад температури у радіальному напрямку розраховують як

$$
\Delta \tau_{o}^{\prime}=\frac{q \cdot b}{6 \lambda_{p}}
$$

де $q$ - поверхнева густина теплового потоку, $b$ - радіальний розмір обмоток, $\lambda_{p}-$ підсумковий коефіцієнт теплопровідності циліндричної обмотки.

Засновуючись на такому підході, кількісна залежність середнього коефіцієнту тепловіддачі в каналах циліндричних обмоток, яку рекомендовано застосовувати для урахування на практиці при визначені середніх і максимальних перевищень температур складатиме

$$
\alpha=\frac{q}{\Delta \pi_{\sharp}^{\prime}}
$$

де $\Delta \tau_{\text {п }}=\Delta \tau_{\mathrm{o}}-\Delta \tau_{o}^{f}-$ перевищення середньої температури поверхні обмоток над середньою температурою масла в баку, $\Delta \tau_{\sigma}$ - температура масла в баку.

Для урахування можливих теплових навантажень трансформатора, при яких змінюється температура масла в баку в межах $35 . . .70 \circ \mathrm{C}$, середній коефіцієнт тепловіддачі у залежності від перегріву рекомендовано визначати емпірично за виразом виду

$$
\alpha=1,064 q^{0,4}\left(\frac{b_{g x}+b_{k}}{2}\right)^{0,25} \Delta \tau_{o}{ }^{0,2},
$$

де $b_{\text {вн }} b_{\text {н }}-$ внутрішній і зовнішній розміри ширини масляного каналу з середини та іззовні циліндричної обмотки відповідно.

Питанню тепловіддачі з поверхні охолодження обмоток трансформатора, як і нагріву, завжди приділялось багато уваги. Так у роботі [3] вказується, що в умовах навіть короткострокового перевантаження трансформатора, визначення середнього перевищення температури обмоток у будь який час складна і надто актуальна задача для трансформатора як неоднорідного середовища. Втрати потужності в обмотках трансформатора пропорційні квадрату сили струму, але і залежать від температури через власний опір. Так, рекомендований у [4] вираз щодо визначення середнього встановленого перевищення температури обмоток при перевантаженні трансформатора має вигляд

$$
\tau_{o y}=\frac{\tau_{a x}\left(1+b k^{2}\right)}{1+b}
$$

в якому $\tau_{\text {он }}$ - номінальне встановлене перевищення температури обмоток, $b$ - відношення втрат в обмотці до втрат в осередді магнитопровода у номінальному робочому режимі РТ, $k$ - кратність струму перевантаження відносно його номінального значення для обмотки.

В роботі [3], яку слід вважати найбільш обґрунтованою, вказується, що при значному перевантаженні РТ, отримані результати за виразом (11) значно занижені. Сутність запропонованого розрахунку автор зводить до перевірці і порівняння допустимої за класом ізоляції температури із робочою температурою. Але при цьому оцінюється не абсолютна температура нагріву, а так званий перегрів $\tau=\theta-\theta_{0}$ над температурою оточуючого середовища і який відповідає номінальній потужності трансформатора.

При застосуванні поняття перегріву, трансформатор буде працювати в припустимому тепловому режимі, коли виконується умова $\tau_{\text {make }} \leq \tau_{\text {доп. Перевірка цієї }}$ умови щодо прямого методу передбачає побудову залежності нагріву голових середовищ $\tau(t)$ і визначення $\tau_{\text {мaw }}$ через встановлене значення температури, яке б відповідало тривалому режиму роботи трансформатора $з$ незмінним навантаженням. Оскільки $\tau_{\text {маке }}$ гіпотетичний показник, то для застосування прямого методу можливо скористатися математичною моделлю теплового стану трансформатора - рівняннями теплового балансу.

Трансформатор за показником теплопровідності неоднорідне у тепловому відношенні тіло і із різноманітним розташуванням джерел тепла та напрямками пересування їх теплових потоків. Відтак у еквівалентній тепловій схемі заміщення трансформатора, наведеній на рисунку 2, неоднорідність враховується розглядом лише трьох основних середовищ - обмоток 1 , магнітопроводу 2 і масла 3 у системі охолодження. Притаманні їм теплофізичні властивості - такі як теплоємність

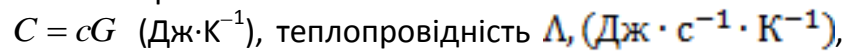
коефіцієнт тепловіддачі $K_{m},\left(Д ж \cdot c^{-1} \cdot \mathrm{K}^{-1} \mathrm{M}^{-2}\right) \mathrm{i}$, за місцем 
наявності, відповідні втрати потужності $P_{i}\left(Д ж \cdot \mathrm{c}^{-1}\right)$, розглядаються незалежними від температури. Автор вважає, що тепловіддача у зовнішнє середовище пропорційна тільки першій ступені різниці температур трансформатора і оточуючого повітря із теплопровідністю $\Lambda_{3}$ по відношенню до масла, а його теплоємність $C=\infty$ і при нагріву трансформатора $\theta_{0}$ не змінюється, залишаючись рівною середньому річному значенню.

Недоліком такого підходу слід вважати нехтування впливом швидкості руху масла у системі охолодження на стан розподілу температури по висоті активної частини трансформатора. Спроба покращити достовірність результатів аналізу теплового стану РТ стикається з потребою ускладнення еквівалентної теплової схеми заміщення і зростанню кількості рівнянь теплового балансу.

Метод еквівалентних теплових схем заміщення прис

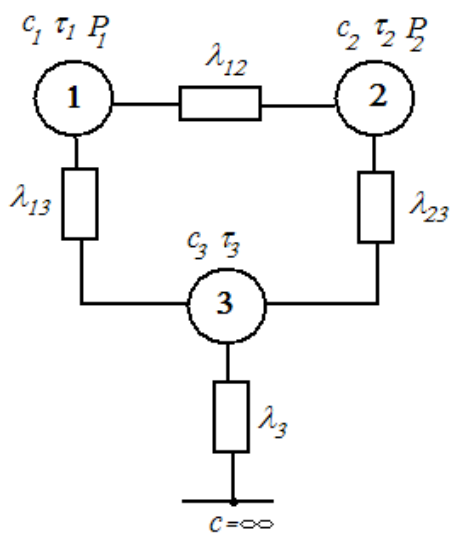

Рисунок 2 - Еквівалентна теплова схема заміщення розподільчого трансформатора за [3]

тосовано до трансформаторів. Робота РТ супроводжується небажаним але незворотним процесом виділення тепла в елементах конструкції під дією втрат в них електричної потужності. Найбільш чутливою до теплового навантаження $€$ ізоляція обмоток. Завищена температура прискорює ії теплове старіння і призводить до зниження діелектричної і механічної стійкості.

На сучасному рівні при аналізі теплових процесів у різноманітних конструкціях трансформаторів, впроваджують різноманітні підходи, серед яких можливо виділити такі як: польові методи; метод еквівалентних гріючих втрат; метод температурних полів; метод еквівалентних схем заміщення тощо. Найбільш простий, 3 точки зору реалізації і забезпечення бажаної точності, яка 6 відповідала вимогам інженерного розрахунку, $€$ метод еквівалентних теплових схем заміщення (ЕTC). Основною перевагою метода ЕТС $€$ суттєве спрощення рішення двомірних процесів теплопровідності. Так як результуючий тепловий потік $є$ сумою взаємодії одномірних потоків, то зустрічний йому еквівалентний тепловий опір визначається як сума паралельних опорів, крізь які проходить одномірний потік у відповідному напрямку. Це припускає аналогію теплового потоку з електричним струмом $I$, яку засновано на спільній формі рівняння теплообміну (закон Фур'є):

$$
P=\frac{\lambda S_{C p}}{\delta} \Delta \tau=\frac{\Delta \tau}{R_{\lambda}}
$$

і електричного струму (закон Ома):

$$
I=\frac{\rho S}{\ell} \Delta U=\frac{\Delta U}{R_{g}},
$$

де $S_{c p}$ - середня площа поверхні, що передає тепло;

$\lambda$ - коефіцієнт теплопровідності; $\Delta \tau$ - падіння температури на довжині $\delta ; R_{\lambda}$ - тепловий опір даної ділянки на шляху теплового потоку; $\rho$ - питома електрична провідність; $\Delta U$ - різниця потенціалів на довжині провідника $\ell$ із перерізом $S ; R_{3}$ - електричний опір.

При складанні еквівалентних теплових схем заміщення між параметрами електричних і теплових кіл використовують наступні співвідношення: електричний струм (A) - тепловий потік (Вт); напруга (B) - температуpa $\left({ }^{\circ} \mathrm{C}\right)$; електричний опір $(\Omega)$ - тепловий опір $\left({ }^{\circ} \mathrm{C} / \mathrm{BT}\right)$; електрична ємність (Ф) - теплова ємність ( Дж/(кг $\left.\left.{ }^{\circ} \mathrm{C}\right)\right)$. Будь яка конструкція трансформатора може бути наданою різноманітними тепловими схемами заміщення, які відрізняються ступенем деталізації можливих шляхів протікання теплових потоків. Головну проблему складатиме точне визначення теплових опорів $R_{\lambda}$ між елементами конструкції трансформатора, в якому виникає виділення тепла, і навколишнім середовищем, а також визначення основних показників, які характеризують інтенсивність його охолодження у випадку застосування системи примусової аксіальної вентиляції (вбудований вентилятор чи продув). Для визначення витрати холодильного агенту або масового розходу (масла або повітря) $Q_{в}\left(\mathrm{M}^{3} / \mathrm{c}\right)$ необхідного для відводу тепла, а також характеру розподілу холодильного агенту і його швидкості на окремих ділянках, необхідно мати дані гідравлічного розрахунку уздовж кільця охолодження у конструкції баку і активної частини трансформатора.

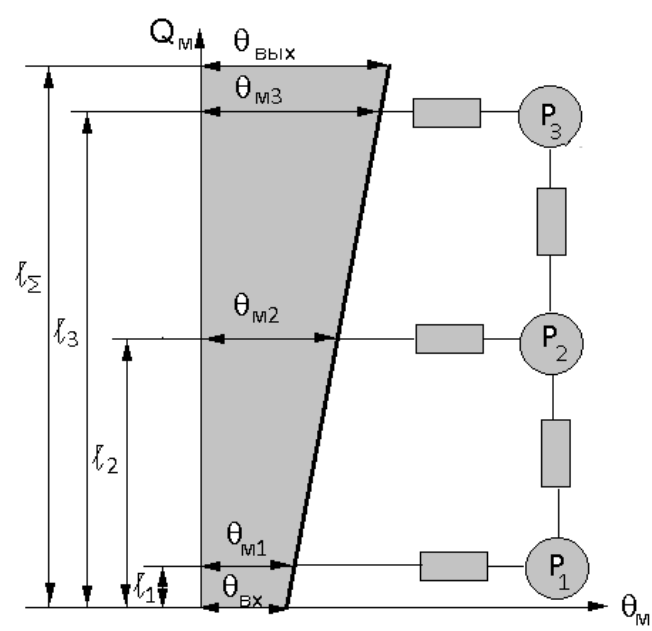

Рисунок 3 - Вплив підігріву охолоджуючого потоку в тепловій схемі заміщення

При математичному моделюванні теплових процесів методом ЕТС приймають наступні припущення: 
-трансформатор розглядається у вигляді системи однорідних елементів;

- елементи конструкції трансформатора повинні мати найпростішу геометричну форму в межах розмірів якої умови нагріву або охолодження залишаються незмінними;

- кожний елемент на схемі заміщення надається у вигляді вузла до якого сходяться опори теплообміну цього елементу із опорами теплообміну інших елементів;

- зосереджені еквівалентні теплові опори, які замінюють дійсні розподілені, не залежать від величини теплового потоку;

- втрати, які виникають в конкретній частині трансформатора, виділяються в вузлах;

- тепловий розрахунок трансформатора зводиться до розрахунку середніх температур усіх вузлів. Для спрощення рішення вважається, що у поперечному перерізі передачі тепла немає. Це дозволяє розглядати площинну задачу із розподілом тепла уздовж подовжнього перерізу трансформатора. Перевищення температури окремих дротів обмотки приймають рівним середньому перевищенню температури обмотки;

- так як теплові опори визначають параметрами середовища (коефіцієнти теплопровідності і тепловіддачі, кінематична в'язкість, теплоємність), які залежать від температури, то під час розрахунку по методу ЕTC задаються приблизними значеннями температур i за якими визначають усі теплотехнічні показники елементів конструкції і охолоджуючого середовища. При застосуванні метода ЕTС теплофізичні показники однорідних елементів, такі як об'ємна теплоємність, коефіцієнт теплопровідності, інтенсивність об'ємно розподілених джерел теплоти і рівняння теплообміну не межах елементів вважаються незмінними для інтервалу температур що розглядається;

- у випадку примусової циркуляції масла в середині бака трансформатора його температура приймається незмінною та такою, що дорівнює середньому значенню між його температурами на вході і виході з охолоджуючих радіаторів, а саме за виразом

$$
\theta_{\mathrm{BH} . \mathrm{cp},}=\frac{\theta_{0}+\theta_{\mathrm{BH}}}{2}=\theta_{0}+\frac{k_{0} \sum P_{\mathrm{rp}}}{2\left(C_{\mathrm{M}} \rho_{\mathrm{M}} Q_{\mathrm{M}}\right)^{2}}
$$

в якому $k_{0}-$ коефіцієнт, враховуючий долю втрат в трансформаторі, що відводяться головним охолоджуючим потоком; $\sum P_{\text {zp. }}$ - сумарні гріючі втрати в трансформаторі, Вт; $C_{M}$ - питома теплоємність масла $\left(\mathrm{BT}^{\circ} \mathrm{C}\right) ; \rho_{M}-$ густина масла (кг/м ${ }^{3}$ ) та його об'єм $Q_{\text {м }}$ в баку.

Розглядаючи метод слід відзначити, що при тепловому розрахунку симетричних по осях систем охолодження трансформаторів, особливо великих за розмірами, не завжди достатньо враховувати тільки середню температуру охолоджуючого потоку всередині бака. У таких випадках постійне зростання температури $\theta_{\text {м }}$ охолоджуючого потоку масла при проходженні ним різноманітних ділянок уздовж обмоток враховується в тепловій схемі за допомогою лінії, яку можливо розгля- дати як сукупність базових точок із температурою, що зростає у напрямку руху потоку $Q_{u}$, рис.3.

Викреслені базові точки схеми мають температури $\theta_{u 1}, \theta_{u 2}$ і $\theta_{u a}$, які і потрібно визначити. При цьому для спрощення визначення базових точок схеми роблять припущення по лінійне зростання температури по висоті трансформатора і базові температури розраховуються заздалегідь:

$$
\begin{aligned}
& \theta_{u 1}=\theta_{a x} \frac{\Delta \ell+\ell_{1}}{\ell_{L}}, \\
& \theta_{u 2}=\theta_{e x} \frac{\Delta \ell+l_{2}}{\ell_{L}}, \\
& \theta_{u a}=\theta_{e x} \frac{\Delta \ell+l_{a}}{l_{\mathrm{L}}} .
\end{aligned}
$$

де $\theta_{\mathrm{ms}}$ - температура знизу в баку трансформатора, ${ }^{\circ} \mathrm{C}$; $\theta=\Delta \theta_{\text {ess }} \quad$ - підігрів повітряного потоку, ${ }^{\circ} \mathrm{C}$;

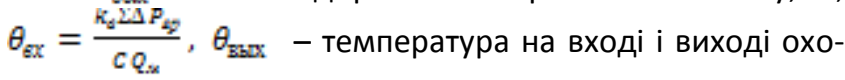
лоджуючого каналу в трансформаторі, ${ }^{\circ} \mathrm{C} ; k_{e}=0,9-$ коефіцієнт, що враховує частку втрат, які відводяться головним охолоджуючим потоком $Q_{u}$ у залежності від застосованої системи охолодження; $\Sigma \Delta P_{z}$ - сумарні гріючі втрати в трансформаторі, Вт; $C$ - питома об'ємна теплопровідність масла при нормальних умовах, (Дж/ $\left.{ }^{\circ} \mathrm{C} \cdot \mathrm{\kappa r}\right) ; \ell_{1}, \ell_{2}, \ell_{\mathrm{a}}, \ell_{\Sigma}$ - довжина відповідних ділянок по висоті, (м).

Застосовуються і інші методи урахування зміни температури охолоджуючого потоку - по мірі його руху уздовж активної частини трансформатора. РТ працюють у широкому діапазоні навантаження та циклічно, а отже, у тривалому, короткостроковому, повторно короткостроковому, перемежаючому режимах або навіть у режимах, які не відповідають нормативам ДСтУ.

Для РТ власних потреб найбільш типовим $€$ повторно коротко часовий режим роботи із навантаженням, яке швидко змінюється, або аналогічний до нього. В цьому випадку тепловий стан трансформатора залежить від тривалості зростання, спаду навантаження (ПВ $=t_{\mathrm{p}} / t_{\text {ц }}$ де $t_{\mathrm{p}}-$ тривалість робочого періоду, $t_{ц}-$ тривалість повного циклу) і величини навантаження.

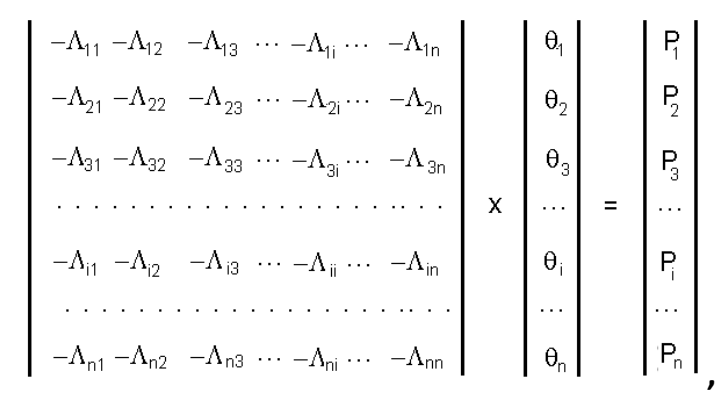

у більшості випадків метод ЕТС застосовується для визначення теплового стану трансформатора у тривалому режимі роботи, але слід відзначити можливість його успішного застосування для розрахунку нестаціонарних робочих режимів, та також режиму роботи по заданій циклограмі навантаження. 
Метод ЕTC дозволяє формалізувати різноманітні практичні задачі розрахунку сталого режиму нагріву у матричному вигляді системи рівнянь теплового балансу (16), де $P_{n}$ - втрати потужності у будь якому з однорідних елементів зі стоками тепла, на які поділено трансформатор; $\Lambda_{n n}$ - теплові провідності елементів.

Якою 6 не була конструкція трансформатора, у тепловому відношенні він завжди складний комплекс вза$є м н о$ пов'язаних елементів, явища в якому математично формалізуються системою диференційних рівнянь Пуассона в часткових похідних, Взаємно пов'язані і взаємно залежні граничні умови для цих рівнянь суттєво ускладнюють їх вирішення. Відмова від розгляду поля температур всередині окремого елементу із стоками тепла дозволяє відображати теплові процеси системою звичних лінійних диференційних рівнянь першого порядку. Їх кількість залежить від кількості елементів, на яке поділено трансформатор. Зазвичай теплова схема заміщення (ТСЗ) охоплює наступні елементи конструкції трансформатора: обмотки ВН і НН; магнітопровід; масло системи охолодження - внутрішнє середовище, бак і радіатори. Усі елементи ТСЗ пов'язані між собою відповідними тепловими провідностями. Джерелами теплоти, зосередженими у відповідних вузлах, є втрати потужності у магнітопроводі та дротах обмоток ВН і НH.

Тепловий стан $n$-го елементу схеми заміщення або рівняння теплової рівноваги у вигляді диференційних рівнянь мають наступний вигляд

$$
C_{n} \frac{d \theta_{n}}{d t}=\sum_{i=1}^{q(i \neq n)} \Lambda_{i n}\left(\theta_{i}-\theta_{n}\right)+P_{n}
$$

де $C_{n}$ - теплоємність $n$-го елементу; $\theta_{n}$ - температура $n$ го елементу; $\theta_{\mathrm{i}}$ - температура одного з сусідніх елементів, пов'язаних у тепловому відношенні із елементом n, що розглядається; $P_{n}$ - втрати потужності у даному елементі $n ; \Lambda_{\text {in }}$ - теплова провідність $i$-го елементу; $t$ час.

3 метою визначення температурного стану трансформатора в цілком вирішують наступну систему диференційних рівнянь

$$
\begin{gathered}
C_{1} \frac{d \theta_{1}}{d t}=\left(-\sum_{i=2}^{m} \Lambda_{i 1}\right) \theta_{1}+\sum_{i=2}^{m}\left(\Lambda_{i 1} \theta_{i}\right)+P_{1} \\
C_{2} \frac{d \theta_{2}}{d t}= \\
\left(-\sum_{i=1}^{k(i \neq 2)} \Lambda_{i 2}\right) \theta_{2}+\sum_{i=1}^{k(i \neq 2)}\left(\Lambda_{i 1} \theta_{i}\right)+P_{2}, \\
C_{n} \frac{d \theta_{n}}{d t}=\left(-\sum_{i=1}^{q(i \neq n)} \Lambda_{i n}\right) \theta_{n}+ \\
\sum_{i=1}^{q(i \neq n)}\left(\Lambda_{i n} \theta_{i}\right)+P_{n}
\end{gathered}
$$

де $m$ - кількість елементів, пов'язаних у тепловому відношенні з першим елементом; $k$ - кількість елементів, пов'язаних у тепловому відношенні із другим елеменTOM.

У подальшому, приймаючи температуру оточуючого середовища за $\theta_{0}$ і вирішуючи наведену систему будь-яким з відомих способів, знаходять середні значення температур елементів для будь якої митті часу $t$. Часткове рішення, при якому $\frac{d \theta_{m}}{d t}=0$, надає стале значення температури елементів у тепловій схемі заміщення. При розрахунку по методу ЕТС вважаються відомими втрати у трансформаторі, теплові опори (провідності) на шляху трансформації цих втрат, витраті охолоджуючої речовини $Q_{u}$ і її швидкість руху навколо поверхонь охолодження та відповідні до них коефіцієнти теплопередачі. До того ж повинна бути відомою температура охолоджуючого середовища $\theta_{0}$ на вході до системи охолодження.

Недоліком методу ЕТС слід вважати те, що він дає усереднені значення температур у окремих елементах трансформатора і не надає повної картини характеру зміни температурного поля тощо.

Класичний метод розрахунку теплового режиму надає більш детальне дослідження теплового стану окремих елементів і вузлів трансформатора та базується на польовому методі.

Головною фізичною величиною, що характеризує процес теплопровідності, $\epsilon$ температура $\theta$, яка, у загальному випадку, змінюється у просторі і часі. Сукупність значень температури в усіх точках заданого простору у часі $t$ розглядається як температурне поле. Якщо температура розглядається функцією тільки просторових координат, то поле $\epsilon$ стаціонарним. Нестаціонарне рівняння теплопровідності або рівняння дифузії Лапласа для ізотропного лінійного простору має вигляд

$$
C_{\gamma} \frac{\partial \theta}{\partial t}=\lambda \nabla^{2} \theta+\mathrm{p},
$$

де $t-$ час, (c); $C$ - питома теплоємність, (Вт/(кг $\left.\left.{ }^{\circ} \mathrm{C}\right)\right) ; y-$

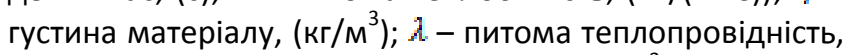
$\left(\mathrm{Bт} /\left(\mathrm{M}^{\circ} \mathrm{C}\right)\right) ; p$ - питомі об'ємні втрати, $\left(\mathrm{BT}^{\prime} \mathrm{M}^{3}\right)$. Якщо температурний режим досяг сталого режиму, а отже $\frac{\partial \theta}{\partial t}=0$, то (19) приймає вигляд рівняння Пуассона

$$
0=\lambda \nabla^{2} \theta+p
$$

У відповідності до (3.20) температура в просторі визначається лише питомою теплопровідністю та об'ємними втратами, які виділяються у стоках тепла. 3 достатньою точністю вважають, що тепловий стан по перерізу об'єктів в трансформаторі $€$ незмінним на деякому віддалені від їх торців і визначається практично тепловим станом в середньому перерізу цих об'єктів. Таким чином, для визначення цього стану достатньо вирішити двомірну задачу Пуассона відносно температури, яка у системі координат $x, y$ (при незмінній теплопровідності $\lambda$ ) матиме вигляд рівняння

$$
\lambda\left(\frac{\partial^{2} \theta}{\partial x^{2}}+\frac{\partial^{2} \theta}{\partial y^{2}}\right)=-q_{s^{*}}
$$

Для вирішення крайової задачі повинні бути відомі розміри розрахункової області, фізичні властивості усіх ії ділянок, густина теплового потоку $q_{s}$ та межові умови. Межові умови для стаціонарної задачі відображають 
умови теплової взаємодії між оточуючим середовищем і поверхнею об'єкту, що розглядається. В теорії теплопровідності застосовують межові умови I, II, III і IV роду, а також інші - у випадку наявності фазових перетворень речовини об'єктів - промерзання, плавлення тощо. Межові умови I роду, або умови Діріхле, задають розподілом заздалегідь відомої температури уздовж розрахункового об'єкту як функції координат $\theta_{s}=\theta_{0}$. Наприклад зовнішня поверхня бака РТ при інтенсивному обтіканні її поверхні рідиною або повітрям з постійною температурою. Межові умови II роду, або умови Неймана, задають розподіл густини теплового потоку на зовнішній межі тіл. Вони бувають однорідні або неоднорідні. Однорідні умови вказують на відсутність теплового потоку через межу тіла (теплоізоляція) і утворюють адіабатичний нагрів об'єкта. Також вони описують вісь симетрії розрахункової області уздовж якої проходить тепловий потік без втрат тобто $d \theta_{g} / d x=0$. Неоднорідні умови задають потужність теплового поглинання при його охолодженні або потужність теплового поглинання при його нагріву високотемпературним джерелом теплоти. Ці умови в РТ не застосовуються. Межовими умовами III роду задається залежність теплового потоку $q_{s}$ на поверхні об'єкта від різниці температур його поверхні $\theta_{g}$ та навколишнього середовища $\theta_{0}$ за допомогою коефіцієнту тепловіддачі (теплообміну) $k, \mathrm{Bт} /\left({ }^{\circ} \mathrm{C} \cdot \mathrm{M}^{2}\right)$, а саме як $q_{s}=k\left(\theta_{g}-\theta_{0}\right)$. Складність у застосуванні коефіцієнту тепловіддачі полягає у тому, що він відображає сумісну дію конвекції, теплопровідності та залежить від розмірів, стану поверхні об'єкта, а також швидкості руху охолоджуючого середовища тощо. Отже, обов'язковою умовою його застосування постає вирішення задачі Нав'є-Стокса до вирішення задачі теплообміну конвекцією та теплопередачею.

При формуванні математичної моделі теплового розрахунку трансформатора зазвичай розглядають дві крайові задачі:

- для області подовжнього перерізу активної частини трансформатора на достатньому віддаленні від його торців (модель першого наближення);

- для частини області подовжнього перерізу, яка відповідає сектору (сегменту) стрижня магнітопроводу з обмотками (модель другого наближення $€$ уточнююча).

В моделі першого наближення структура і фізичні властивості обмоток, магнітопроводу задаються приблизно і усередненими. Зовнішньою межею області розрахунку приймається зовнішня поверхня бака РТ з межовими умовами I роду $\theta_{s}=\theta_{0}$.

В моделі другого наближення виконують деталізацію обмоток ВН та НH, а межові умови отримують 3 попереднього розрахунку за моделлю першого наближення.

Як і попередні методи теплового розрахунку класичний метод базується на припущеннях, які впливають на точність теплового розрахунку, а саме:

- температурне поле на значній відстані від поверхні бака вважається плоско паралельним, тобто пере- дачі тепла вздовж тангенціальної вісі трансформатора не існує;

-температура охолоджуючого середовища $€$ незмінною;

- перемішування масла в середині бака не враховується.

Результатом застосування класичного методу щодо вирішення задачі теплового розрахунку РТ постають розподіл температур і їх градієнтів, густини теплового потоку і її інтегральне значення крізь задані поверхні.

CFD - технологія моделювання теплових режимів в обмотках масляних трансрорматорів, яка розглядається у [13], заснована на отримані бажаних результатів шляхом використання методу математичного моделювання сумісних процесів гідродинаміки і теплообміну на підставі застосування сучасного програмного забезпечення від провідних світових виробників. Прикладом такого програмного забезпечення $\in$ STAR CD, FLUENT, CFX [24] тощо. Спільним для них $\epsilon$ те, що в них використовуються CFD (Computational Fluid Dynamics) методи, засновані на спільних універсальних математичних моделях процесу пересування теплоти і речовини, а також використовується набір апробованих, ефективних і високої точності чисельних алгоритмів. Таке програмне забезпечення дозволяє будувати CFD-моделі у вигляді фізико-математичного цифрового надання досліджуваного об'єкта або процесу із рішенням рівнянь флюїдної динаміки Нав'є-Стокса. Сумісна постановка задачі флюїдної динаміки і теплового розрахунку дозволяє позбавитись потреби щодо спрощення сумісних процесів і завдання коефіцієнтів тепловіддачі на поверхнях обтікання твердих тіл досліджуваної системи маслом. Таким чином, CFD-моделі теплового стану в сумісній постановці позбавлені недоліків, притаманних методам розрахунку усереднених температур, і $€$ потенційно більш точними й інформативними, не дивлячись на віртуальний засіб моделювання. Такі можливості вважаються більш перспективними, а їх розробка та впровадження при проектуванні $€$ актуальною задачею.

\section{Література}

1. Швиндер А. В., Чередниченко Г. В., Михайловский Ю. А./ Исследование теплоотдачи цилиндрических обмоток трансформаторов с систематми охлаждения ДЦ и Ц/ Электротехника, №4, 1978, С.47-50.

2. Готтер Г. Нагревание и охлаждение электрических машин. М., Госэнергоиздат, 1961. 480 с.

3. Овчаров В. В. Нагревание обмотки трансформатора при перегрузке / В. В. Овчаров // Электротехника. 1975. - № 4. - С. 56-57

4. Шницер Л. М. Основы теории и нагрузочная способность трансформаторов. М.-Л., Госэнергоиздат, 1959.

5. Котенев С.В., Евсеев А.Н. Расчет теплового режима для трансформатора тороидального типа // Практическая силовая электроника, 2003, № 10, С. 21-25.

6. Каретникова Е.Н., Рычина Т.А., Ермаков А.И. Трансформаторы питания и дроссели фильтров для радио- 
электронной аппаратуры. М.: Советское радио. 1975. $180 \mathrm{c}$.

7. Горский А.Н., Русин Ю.С., Иванов Н.Р., Сергеева Л.А.. Расчет электромагнитных элементов источников вторичного электричества. М.: Радио и связь. 1988. - 176 с. 8. Карташов Э.М. Аналитические методы и теории теплопроводности твердых тел. М.: Высшая школа. 1985. 480 c.

9. Силовые трансформаторы. Справочная книга. М.: Энергоиздат. - 2004.- 614 с.

10. Готтер Г. Нагревание и охлаждение электрических машин: Пер. с нем. Под ред. В. В. Мальцева - М.: Госэнергоиздат, 1961. - 480 с.

11. Киш Л. Нагрев и охлаждение трансформаторов / Пер. с венгерского. По. Ред. Г. Е. Тарле. - М.: Энергия, 1980. - 208 с. ил. - (трансформаторы; Вып. 36).

12. Шидловский А. К., Воеводин И. Д., Мелешко Ю. И. Основные тенденции развития трансформаторостроения за рубежом. - Киев; Институт электродинамики АН УССР - 1986.- 32 с. (препр. / АН Украины. Ин-т электродинамики; Препринт - 479).

13. Воеводин И. Д., Михайловский Ю. А. и др. Методы расчета превышений температуры обмоток силовых трансформаторов // Трансформаторы: Перенапряж. и координация изоляции. Пер. докл. Междунар. конф. по больш. электр. Системам СИГРэ -84. М.: - 1986. С. 190-198.

14. Дулькин И. Н., Люблин И. Ш. Метод теплового расчета обмоток силовых масляных трансформаторов // Электротехника. - 1997. - №2. - С. 16-22.

15. Oliver A. J. (1980) Estimation of transformer winding temperatures and coolant flows using a general network method // IEE Proc., Vol. 127. Pt.C. No. 6. November. - P. 395-405/

16. Robert M. Del Vecchio, Bertrand Poulin, Pierre T. Feghali, Dilipkumar M. Shah and Rajendra Ahuja (2001). Transformer design principles: with application to core- form transformers // Gordon and Breach Science Publishers.. - $559 \mathrm{~s}$.

17. Seitlinger Walter. Thermo- Hydraulic transformer model. VA TECH Elin Transformatoren GmbH. 2000. http:// www.vatechtd.com.

18. Mufuta J.-M., Eric van den Bulck (2000). Modelling of the mixed convection in the winding of the a disc- type power transformer // applied Thermal Engineering 20. - P. 417-437. http:www.elsevier.com.

19. Кучерявая И. Н. Численное исследование влияния различных факторов процесса теплообмна на эффективность охлаждения трансформаторновыпрямительных модулей // Техн. Электродинамика. 2000. - №3. - С. 56-61.

20. Козлов В. В. Підвищення ефективності примусового охолодження високовольтних масляних трансформаторів Автореф. дис... канд. техн. наук: 05.09.01 /; Нац. техн. ун-т: «Харк. політехн. ін-т», - Х., 2004. - 19 с.

21. Рассальський О. М. Аналіз і розрахунок теплових режимів силового електроустаткування: / М-во освіти і науки України, Запоріз. нац. техн. ун-т. - Запоріжжя: ЗНТУ, 2005. - 144 с.

22. Одаренко Ю. М. Розвиток методів подібності при теплообміні в охолоджуючих каналах обмоток трансформаторів для удосконалення їх теплового захисту. Автореферат дис... канд. техн. наук: 05.14.06/ Дніпродзержинський держ. техн. ун-т. Дніпродзержинськ: 2006.- 19 c.

23. Tanguy A., Patelli J. P., Devaux F., Taishe J. P., Ngnegueu T. (2004) Thermal performance of power transformers: thermal calculation tools focused on new operating requirements. Presented at CIGRE Session, CIGRE, Paris, France, Session, Report Nr. A2-105.

Отримана в редакції 09.01.2017, прийнята до друку 07.02.2017

\title{
Simulation of Convective Heat Transfer by Oil from the Distribution Transformer Surface
}

\author{
Y.V. Baidak ${ }^{1}$, M. Masaryk ${ }^{2}$, V.A. Matukhno ${ }^{3}$ \\ ${ }^{1}$ Odessa National Academy of Food Technologies, 112, Kanatnaya str, 65039, Odessa, Ukraine \\ ${ }^{2}$ Slovak University of Technology in Bratislava, Faculty of Mechanical Engineering, \\ Námestie slobody 17, 82131 Bratislava, Slovak Republic \\ ${ }^{3}$ Odessa National Polytechnic University, Department of Electrical Machines, 1 Shevchenko Ave., Odessa, 65044, Ukraine
}

During operation of electrical equipment and its design there is always a need to solve the problem of its heating and cooling, and especially the heating and cooling problem of the windings insulation as the most sensitive construction element The successful solution of the problem promote creation economically reliable equipment and the formation of a reasonable usage. The result of the study is the expediency substantiation of heat balance equations drawn up for the active part of the voltage distribution transformer simulation results implementation, at the final and qualifying design stage. The active part is in the transformer oil environment, and emission of heat is carried out by convection and heat transfer. The heat balance mathematical model corresponds to the equivalent thermal circuit, consisting of two adjacent units with heat outlet - generalized winding and ferromagnetic core and the third unit which is adjacent to them - moving substance from the oil which additionally contacts with the environment of infinite heat capacity. 
The solutions of equations are obtained for the winding mean temperatures, magnetic circuit core and oil in function of time that allows to determine their expected values during the transformer operation, and especially with the uneven schedule of its load as well as to make the justified choice of magnetic induction in the magnetic circuit core and current density in the windings in terms of permissible heating temperatures in them.

Keywords: Simulation - Distribution Transformer - Thermal balance - Time diagrams of temperatures - Chart load Thermal Subsystem

\section{References}

1. Shvinder, A. V., Cherednichenko, G. V., Mihaylovskiy, Yu. A. (1978) Issledovanie teplootdachi tsilindricheskih obmotok transformatorov $\mathrm{s}$ sistematmi ohlazhdeniya DTs i Ts. Elektrotehnika, No.4, 47-50.

2. Gotter, G. (1961) Nagrevanie i ohlazhdenie elektricheskih mashin. M., Gosenergoizdat, 480 p.

3. Ovcharov, V.V. (1975) Nagrevanie obmotki transformatora pri peregruzke. Elektrotekhnika, No.4, 56-57.

4. Shnitser, L. M. (1959) Osnovy teorii i nagruzochnaia sposobnost transformatorov. M.-L., Gosenergoizdat.

5. Koteneev, S.V., Evseev, A.N. (2003). Raschet teplovogo rezhima dlya transformatora toroidalnogo tipa. Prakticheskaya silovaya elektronika, No. 10, 21-25.

6. Karetnikova, E. N., Ryichina, T.A., Ermakov, A. I. (1975) Transformatory pitaniia i drosseli filtrov dlia radioelektronnoi apparatury. M.: Sovetskoe radio, 180 p.

7. Gorskiy, A. N., Rusin, Yu. S., Ivanov, N. R., Sergeeva, L. A. (1988) Raschet elektromagnitnyih elementov istochnikov vtorichnogo elektrichestva. M.: Radio i sviaz. $176 \mathrm{p}$.

8. Kartashov, E.M. (1985) Analiticheskie metody i teorii teploprovodnosti tverdyh tel. M.: Vyisshaya shkola. 480 p.

9. Silovyie transformatoryi. (2004) Spravochnaya kniga.

M.: Energoizdat. 614 p.

10. Gotter, G. (1961) Nagrevanie i ohlazhdenie elektricheskih mashyn: Ed V. V. Maltseva. M.: Gosenergoizdat, $480 \mathrm{p}$.

11. Kish, L. (1980) Nagrev i ohlazhdenie transformatorov. Ed. G. E. Tarle. M.: Energia, 208 p. (Transformatory, vyp. 36).

12. Shidlovskiy, A. K., Voevodin, I. D., Meleshko, Yu. I. (1986) Osnovnyie tendentsii razvitiya transformatorostroeniya za rubezhom. Kiev, Institut elektrodinamiki AN USSR, 32 p. (prepr. / AN Ukrainy. In-t elektrodinamiki; Preprint - 479).

13. Voevodin, I. D., Mihaylovskiy, Yu. A. (1986) Metodyi rascheta prevyisheniy temperaturyi obmotok silovyih transformatorov // Transformatoryi: Perenapryazh. i koordinatsiya izolyatsii. Per. dokl. Mezhdunar. konf. po bolsh. elektr. Sistemam SIGRE -84. M., 190-198.
14. Dulkin, I. N., Lyublin, I. Sh. (1997) Metod teplovogo rascheta obmotok silovyih maslyanyh transformatorov. Elektrotehnika, No. 2, 16-22.

15. Oliver, A. J. (1980) Estimation of transformer winding temperatures and coolant flows using a general network method. IEE Proc., Vol. 127. Pt.C. No. 6. November, 395-405

16. Robert M. Del Vecchio, Bertrand Poulin, Pierre T. Feghali, Dilipkumar M. Shah, Rajendra Ahuja (2001) Transformer design principles: with application to coreform transformers. $559 \mathrm{p}$.

Doi: https://doi.org/10.1201/9781420021943

17. Seitlinger Walter. (2000) Thermo- hydraulic transformer model. VA TECH Elin Transformatoren GmbH. URL: http://www.vatechtd.com

18. Mufuta, J.-M., Eric van den Bulck (2000). Modelling of the mixed convection in the winding of the a disc-type power transformer. Applied Thermal Engineering, 20, 417437. Doi: http:www.elsevier.com.

19. Kucheryavaya, I. N. (2000) Chislennoe issledovanie vliyaniya razlichnyih faktorov protsessa teploobmna na effek-tivnost ohlazhdeniya transformatornovyipryamitelnyih moduley. Tehn. Elektrodinamika, No.3, 56-61.

20. Kozlov, V. V. (2004). PIdvischennya efektivnostl primusovogo oholodzhennya visokovoltnih maslyanih transformatorlv. Avtoref. dis... kand. tehn. nauk: 05.09.01 $19 \mathrm{p}$.

21. Rassalskiy, O. M. (2005) Analiz i rozrahunok teplovyh rezhymiv silovogo elektroustatkuvannia. Zaporizhzhia, ZNTU, $144 \mathrm{p}$.

22. Odarenko, Yu. M. (2006) Rozvitok metodiv podibnosti pri teploobmini $\mathbf{v}$ oholodzhuyuchih kanalah obmotok trans-formatoriv dlia udoskonalennya ih teplovogo zahistu. Avtoreferat dis... kand. tehn. nauk: 05.14.06. Dniprodzerzhinskiy derzh. tehn. un-t. Dniprodzerzhinsk: 19 p.

23. Tanguy, A., Patelli, J. P., Devaux, F., Taishe, J. P., Ngnegueu, T. (2004) Thermal performance of power transformers: thermal calculation tools focused on new operating requirements. Presented at CIGRE Session, CIGRE, Paris, France, Session Report No. A2-105. 